REPORTS OF MORPHOLOGY
$\begin{gathered}\text { Official Journal of the Scientific Society of Anatomists, } \\ \text { Histologists, Embryologists and Topographic Anatomists } \\ \text { of Ukraine } \\ \text { journal homepage: https://morphology-journal.com }\end{gathered}$

\title{
Features of the relationship between cardiointervalographic indices and constitutional characteristics in highly skilled mesomorphic somatotype wrestlers
}

\author{
Syvak A.V. ${ }^{1}$, Sarafyniuk L.A. ${ }^{1}$, Sarafyniuk P.V. ${ }^{2}$, Pilhanchuk L.I. ${ }^{1}$, Sorokina N.O. ${ }^{1}$ \\ ${ }^{1}$ National Pirogov Memorial Medical University, Vinnytsya, Ukraine
} ${ }^{2}$ Vinnitsia State Mykhailo Kotsyubynskyi Pedagogical University, Vinnytsya, Ukraine

\section{ARTICLE INFO}

Received: 20 September, 2019

Accepted: 28 October, 2019

UDC: $612.172: 572.51: 796.42$

\section{CORRESPONDING AUTHOR}

e-mail: sivak198740@gmail.com Syvak A.V.

\begin{abstract}
Mechanisms of regulation of cardiac rhythm have many individual features, which are conditioned by age, sex, training of the organism, strength and nature of external influence, constitutional features of the organism. The purpose of the work is to determine the relationship between cardiointervalographic indices and parameters of the external structure of the body in highly skilled wrestlers of the mesomorphic somatotype. The study involved 24 wrestlers between the ages of 17 and 21 with a high level of sportsmanship and more than 3 years of experience. All of the wrestlers were of medium weight and engaged in free and Greco-Roman wrestling. We conducted a study of heart rate variability on the cardiac computer diagnostic complex "OPTW" following the recommendations of the European and North American Cardiac Association (1996). The indices of vegetative homeostasis according to Bayevsky, variational heart rate, statistical and spectral cardiointervalographic indicators were determined. Anthropometry was performed according to the method of V.V. Bunak (1941), somatotypological study - by the calculated modification of the Heath-Carter method (1990), determination of the component composition of body weight by the method of Matejko (1992). In the package "STATISTICA 5.5" correlation analysis was performed using the nonparametric Spearman statistical method. It was found that in the wrestlers of the mesomorphic somatotype, the variations of the pulsometry had the highest number and strength of reliable correlations with constitutional parameters, most of which were inverse of the mean force. All statistical indicators of heart rate variability with indicators of the external structure of the body had only inverse significant correlations. The least significant correlations were found for spectral indices and parameters of vegetative homeostasis. According to the results of the correlation analysis in the wrestlers of the mesomorphic somatotype, we can assume that with the increase of total, longitudinal, circumferential, transverse body sizes and muscle and bone mass, the variability of the heart rhythm of the sympathetic department of the autonomic nervous system will be more pronounced.

Keywords: correlations, cardiointervalographic indices, anthropometric dimensions, somatotype, wrestlers.
\end{abstract}

\footnotetext{
Introduction

Achieving high athletic performance is closely linked to the effective training of athletes in specialized training centers [8, 24]. One of the most important principles of building a training process is to match the loads to the current functional state $[2,24]$. In order to improve and predict the athletic performance of athletes today, a simple method of examination, such as determining heart rate variability, is used in sports medicine and cardiology to effectively evaluate the balance of all nervous system components
}

and make prognosis in reaching sports peaks [14, 22, 23].

Thus, the use of excessive daily physical training by young athletes causes not only a feeling of general fatigue, but also requires a significant overall mobilization of all structural and functional resources of the body and systems, which leads to maladaptation, physical overstrain and overtraining [1]. All these factors overstress the mechanisms of adaptation over time lead to a decrease in the protective mechanisms of the body of athletes and provoke diseases 
of the cardiovascular system [1,20].

According to some authors $[13,16]$, the objective criteria for assessing the current functional status and physical fitness of athletes are physiological indicators that reflect the state of the mechanisms of vegetative regulation of cardiac activity. A non-invasive method of analyzing heart rate variability, such as cardiointervalography, has become widespread. It is used to evaluate the vegetative regulation of physiological functions, from the point of view of objectivity there is no doubt $[17,25]$. This method allows to record disturbances of neurohumoral equilibrium, participation of sympathetic and parasympathetic, nervous and humoral units in regulation of heart rate, degree of centralization of its management [17]. Mechanisms of regulation of cardiac rhythm have many individual features, which are due to age, sex, body training, strength and nature of external influence [6, 9, 11]. In recent years, studies have been conducted to identify the relationship between heart rate variability and features of the external structure of the body $[7,19]$. However, studies on the relationship between heart rate variability and anthropometric parameters in wrestlers of a particular constitutional type have not been conducted at all.

The aim of our work was to determine the relationship between cardiointervalographic indices and parameters of the external structure of the body in highly trained wrestlers of the mesomorphic somatotype.

\section{Materials and methods}

We hane conducted on the basis of the research center of National Pirogov Memorial Medical University, Vinnytsya comprehensive survey of highly skilled (from the first adult category to masters of sports) athletes aged 17 to 21 years, who have been engaged in more than three years of wrestling (free and Greco-Roman). All athletes belonged to the middle weight categories, were in the preparatory period of the training annual macrocycle. The determination of the constitutional features of the body of wrestlers was based on an anthropometric study conducted by the Bunak method [4] and somatotypological - by Heath-Carter [5]. In addition, the component composition of body weight was determined by the method of Matejko [10]. After the somatotypological analysis, 24 wrestlers with a mesomorphic somatotype were selected.

Determination of heart rate variability in wrestlers was performed on the "OPTW" computer diagnostic complex, following the recommendations of the European and North American Cardiac Association [12]. Four groups of indicators were defined: statistical (SDNN is the standard deviation of the length of normal R-R intervals, RMSSD is the square root of the sum of squares of the difference of successive pairs of normal R-R intervals, PNN50 is the percentage of the number of pairs of consecutive normal $\mathrm{R}-\mathrm{R}$ intervals that is more than $50 \mathrm{~ms}$ the total number of consecutive pairs of intervals); variational heart rate (mode, mode amplitude, mean, minimum and maximum $R-R$ intervals, variational swing); spectral (total recording power in all bands, power in very low frequencies, power in low frequencies, power in high frequencies, power ratio in the low and high frequencies); indices of vegetative homeostasis, which was determined by the Baevsky method (vegetative rhythm index and voltage indices of regulatory systems and vegetative equilibrium).

Correlation analysis was performed in the "STATISTICA 5.5" package (license number AXXR910A374605FA) using the nonparametric Spearman method.

\section{Results}

After performed correlation analysis, it was found that most indices of variational heart rate with anthropometric parameters of the body had a considerable amount of average strength of reliable connections. It was found that the mode had significant inverse correlations of medium and high strength with the following parameters: body length $(r=-0.45, p=0.027)$, body weight $(r=-0.51, p=0.012)$, body surface area $(r=-0.45, p=0.026)$, height of the upper thoracic point $(r=-0.59, p=0.002)$, height of the pubic point $(r=-0.40, p=0.050)$, height of the shoulder point $(r=-0.43$, $p=0.035)$, finger point height $(r=-0.61, p=0.001)$, width of distal shoulder epiphyses $(r=-0.40, p=0.050)$, hips $(r=-0.67$, $p=0.001)$, lower legs $(r=-0.67, p=0.001)$, shoulder girths in the unstressed state $(r=-0.40, p=0.050)$, upper arms at the top $(r=-0.45, p=0.028)$, at the bottom $(r=-0.40, p=0.050)$, hips $(r=-0.61, p=0.002)$, lower legs $(r=-0.46, p=0.024)$, waist $(r=-0.42, p=0.039)$, chest on inhalation $(r=-0.49, p=0.015)$, exhalation $(r=-0.50, p=0.013)$, at rest $(r=-0.56, p=0.005)$, anterior-posterior mid-thoracic diameter $(r=-0.77, p=0.001)$; transverse thorax diameter $(r=-0.48, p=0.018)$, transverse thorax diameter $(r=-0.52, p=0.009)$, interspinous distance $(r=-0.54, p=0.006)$, intercristal distance $(r=-0.58, p=0.003)$, intertrochanteric distance $(r=-0.70, p=0.001)$, mesomorphic component of the somatotype $(r=-0.47, p=0.021)$, muscular $(r=-0.68, p=0.001)$ and bone $(r=-0.74, p=0.001)$ body weight. Fairly straight, the average strength of the relationship was between the indices of mode in the thickness of the skin and fat folds on the abdomen $(r=0.41, p=0.049)$, on the thigh $(r=0.58, p=0.003)$ and the lower leg $(r=0.41, p=0.050)$.

The amplitude of the mode had only one significant mean feedback in relation to the width of the shoulders ( $r=-$ $0.45, p=0.028$ ), with all other anthropometric indicators found to be unreliable correlations. It was found that the average $R-R$ interval in mesomorph wrestlers had numerous inverse mean and individual strong relationships with the external structure of the body, in particular: with length $(r=-0.43, p=0.034)$, mass $(r=-0.47$, $p=0.022)$ and the surface area of the body $(r=-0.43$, $p=0.038)$, height of the upper thorax $(r=-0.56, p=0.005)$, pubic $(r=-0.40, p=0.050)$, shoulder $(r=-0.40, p=0.050)$, finger $(r=-0.48, p=0.019)$ anthropometric points, width of the distal femoral epiphysis $(r=-0.47, p=0.020)$ and lower leg $(r=-$ $0.61, p=0.002$ ), shoulder girth in a non-stressed condition $(r=-0.41, p=0.049)$, upper arm girth $(r=-0.41, p=0.049)$, girth 
of the thigh $(r=-0.61, p=0.001)$, shin girth at the top $(r=-0.40$, $p=0.050)$, chest girth on inhalation $(r=-0.47, p=0.022)$, exhalation $(r=-0.42, p=0.043)$ and calm state $(r=-0.46$, $p=0.025)$, transverse lower thoracic diameter $(r=-0.45$, $p=0.026)$, anterior-posterior mid-thoracic diameter $(r=-0.57$ $p=0.004)$, interspinous $(r=-0.41, p=0.050)$, intercristal $(r=-$ $0.45, p=0.027)$, intertrochanteric $(r=-0.54, p=0.007)$ pelvis distances, muscle $(r=-0.58, p=0.003)$ and bone $(r=-0.55$, $\mathrm{p}=0.006$ ) body weight.

The maximum $R-R$ interval in wrestlers correlated with body length $(r=-0.41, p=0.050)$, body weight $(r=-0.42$, $p=0.040)$, body surface area $(r=-0.41, p=0.050)$, and upperthoracic height $(r=-0.46, p=0.023)$ and finger $(r=-0.39$, $p=0.050)$ points, width of the distal tibial epiphysis $(r=-0.43$, $p=0.035)$, hip girth $(r=-0.48, p=0.017)$, interspinous distance $(r=-0.40, p=0.050)$, intercristal $(r=-0.41, p=0.049)$ and intertrochanteric distance $(r=-0.53, p=0.007)$, muscle $(r=-0.57, p=0.004)$ and bone mass $(r=-0.40, p=0.050)$ of the body. And the minimum $R-R$ interval had both feedbacks and direct correlations, in most cases they were average. Feedbacks were found with the height of the upper thoracic $(r=-0.44, p=0.031)$ and finger $(r=-0.60, p=0.002)$ points, the width of the distal femoral epiphysis $(r=-0.52$, $p=0.010)$, the lower leg $(r=-0.58, p=0.003)$, hip girth $(r=-$ $0.43, p=0.037)$, anterior-posterior mid-thoracic diameter $(r=-0.56, p=0.004)$, interspinous $(r=-0.44, p=0.032)$, intercristal $(r=-0.41, p=0.050)$ and intertrochanteric $(r=-0.50$, $p=0.013)$ distances of the pelvis, muscle $(r=-0.47, p=0.022)$ and bone ( $r=-0.57, p=0.004)$ weight; and direct connections with the thickness of the skin-fat folds on the forearm $(r=0.49, p=0.016)$, at the lower blade angle $(r=0.42$, $p=0.040)$, abdomen $(r=0.57, p=0.004)$, hips $(r=0.61$, $p=0.002)$, the shin $(r=0.55, p=0.006)$, and the endomorphic component of the somatotype $(r=0.40, p=0.050)$.

Variation span with indicators of external structure of the body had significant only inverse correlations, in particular with the circumference of the hips $(r=-0.45$, $p=0.028)$, the thickness of the skin-fat folds on the back $(r=-0.41, p=0.047)$ and the front $(r=-0.44, p=0.028)$ of the shoulder surface, the thickness of the skin-fat folds on the chest $(r=-0.46, p=0.023)$, with body fat $(r=-0.43, p=0.038)$.

The SDNN heart rate variability statistic was significantly correlated with the thickness of the skin and fat folds on the posterior surface of the shoulder $(r=-0.43, p=0.037)$ and chest $(r=-0.41, p=0.049)$ and muscle mass $(r=-0.41$, $\mathrm{p}=0.049)$. RMSSD had numerous significant inverse correlations: with body length $(r=-0.58, p=0.003)$, body weight $(r=-0.43, p=0.037)$, body surface area $(r=-0.55$, $p=0.006)$, height of upper thoracic $(r=-0.50, p=0.012)$ and finger $(r=-0.40, p=0.050)$ anthropometric points, width of distal shoulder epiphysis $(r=-0.41, p=0.049)$, shoulder girth in tension $(r=-0.47, p=0.022)$, non-stressed state $(r=-0.51$, $p=0.012)$, upper arm circumference $(r=-0.58, p=0.003)$ and lower $(r=-0.63, p=0.001)$, hip circumference $(r=-0.54$, $p=0.007)$, lower legs in the upper $(r=-0.47, p=0.020)$ and lower $(r=-0.46, p=0.023)$ parts, neck $(r=-0.42, p=0.043)$, waist $(r=-0.49, p=0.016)$, foot $(r=-0.44, p=0.031)$, chest inhalation $(r=-0.53, p=0.008)$, exhalation $(r=-0.43, p=0.036)$ and in a calm state $(r=-0.44, p=0.034)$, interspinous ( $r=-$ $0.41, p=0.046)$, intercristal $(r=-0.45, p=0.028)$, intertrochanteric $(r=-0.58, p=0.003)$ distances, muscle $(r=-$ $0.69, p=0.001)$ and bone $(r=-0.46, p=0.023)$ body weight. PNN50 had significant, inverse, mean correlation strength with body length $(r=-0.41, p=0.049)$, suprathoracic height $(r=-0.43, p=0.035)$ and finger $(r=-0.41, p=0.047)$ points, the circumferential dimensions of the forearm in the upper ( $r=-$ $0.41, p=0.048)$ and lower $(r=-0.39, p=0.050)$ parts, hips $(r=-0.46, p=0.025)$, lower legs in the upper $(r=-0.39$, $p=0.050)$ and lower $(r=-0.43, p=0.034)$ parts, waist $(r=-0.40$, $p=0.050)$, chest on inhalation $(r=-0.43, p=0.037)$, anteriorposterior mid-thoracic diameter $(r=-0.45, p=0.027)$, interspinous $(r=-0.41, p=0.047)$, intertrochanteric $(r=-0.51$, $p=0.010$ ) pelvis distances and bone mass determined by the Matejko method $(r=-0.55, p=0.005)$.

Most spectral indicators of heart rate variability in wrestlers of the mesomorphic somatotype did not have numerically significant correlations with anthropometric and somatotypological parameters.

Total recording power in all ranges had only two significant direct correlations: the width of the distal shoulder epiphyses $(r=0.47, p=0.021)$ and the forearm $(r=0.46, p=0.024)$. The spectral index, which reflects the power at very low frequencies, had reliable direct relations of the average force with the body weight $(r=0.47, p=0.019)$, the area of the body $(r=0.40, p=0.050)$, the heights of the upper thorax $(r=0.40), p=0.050)$, pubic $(r=0.56, p=0.005)$, brachial $(r=0.50, p=0.013)$, and finger $(r=0.50, p=0.014)$ points, width of distal shoulder epiphyses $(r=0.54, p=0.006)$ and forearm $(r=0.67, p=0.001)$, lower arm circumference $(r=0.48, p=0.019)$, lower leg $(r=0.41, p=0.049)$, brush $(r=0.41, p=0.044)$, bone mass $(r=0.51, p=0.011)$.

It was found that the power in the low-frequency range of mesomorph wrestlers had a reliable feedback only with the height of the trochanter point $(r=-0.41, p=0.049)$ and the intercristal distance of the pelvis $(r=-0.41, p=0.047)$. Power in the high-frequency range had only one significant indirect relationship with the width of the distal tibial epiphysis $(r=0.41, p=0.046)$. The ratio of power in the low and high frequencies had significant inverse mean force due to the height of the upper thoracic $(r=-0.49, p=0.015)$ and finger $(r=-0.42, p=0.039)$ points and anterior-posterior midthoracic diameter $(r=-0.43, p=0.036)$.

Indicators of vegetative homeostasis, determined by the Bayevsky method, had only direct reliable correlations with constitutional characteristics. Thus, the voltage index of the regulatory systems was correlated with the height of the upper thoracic $(r=0.52, p=0.009)$, shoulder $(r=0.45$, $p=0.027)$, finger $(r=0.41, p=0.050)$ points and muscle mass $(r=0.40, p=0.050)$. The vegetative equilibrium index had $a$ small number of direct reliable mean correlation strengths: with the height of the upper thoracic point $(r=0.43, p=0.038)$, the intertrochanteric distance $(r=0.41, p=0.044)$, muscular 
$(r=0.42, p=0.042)$ and bone mass $(r=0.44, p=0.037)$. Vegetative rhythm index had the highest number of relationship reliability; it correlated with length $(r=0.40$, $p=0.050)$, mass $(r=0.49, p=0.014)$, and body surface area $(r=0.46, p=0.025)$, height of the upper thoracic $(r=0.56$, $p=0.004)$, pubic $(r=0.41, p=0.050)$, humerus $(r=0.49$, $p=0.015)$, finger $(r=0.41, p=0.050)$ points, distal width shoulder epiphysis $(r=0.42, p=0.039)$, girth of thigh $(r=0.45$, $p=0.027)$, thighs $(r=0.43, p=0.038)$, chest inhalation $(r=0.47$, $p=0.020)$, exhalation $(r=0.48, p=0.019)$ and at rest $(r=0.46$, $p=0.022)$, anterior-posterior mid-thoracic size $(r=0.43$, $p=0.036)$, the intercristal $(r=0.44, p=0.032)$, the intertrochanteric distance $(r=0.49, p=0.015)$, the thickness of the skin-fat folds on the back surface of the shoulder $(r=0.41, p=0.047)$, and the chest $(r=0.45, p=0.029)$, muscle $(r=0.52, p=0.009)$ and bone $(r=0.52, p=0.009)$ body weight.

\section{Discussion}

Analyzing the peculiarities of correlations between cardiointervalographic parameters and indicators of external body structure in mesomorph wrestlers, it is necessary to note a much greater number and strength of revealed reliable relationships, unlike the group of athletes who also belonged to this somatotype, as noted in our previous studies [18]. In addition, it was found that the wrestlers of the mesomorphic somatotype had more numerical correlations between the femur rheographic parameters and constitutional characteristics than the athletes [15].

To summarize our results, it should be noted that most indicators of variational heart rate have numerous reliable correlations with anthropometric dimensions and components of somatotype and body weight. In particular, mode among youth wrestlers is correlated with the majority of constitutional parameters (31 out of 49 ), which is $63.3 \%$, of which inverse strong correlations were $16.3 \%$, inverse mean strength $-40.8 \%$, only with a thickness of 3 skin-fat folds $(6.1 \%)$ correlations were direct, medium power. Based on this, we can assume that by increasing the total, longitudinal, girth size of the body, width of the distal epiphyses of the thigh and tibia, diameters of the chest and pelvis, muscle and bone components of somatotype and body weight, and at the same time reduce the fat deposition in the lower ankles of the mesomorphic somatotype wrestlers, the mode will decrease, and thus the level of functioning of the sinus node will be more pronounced [3, 25]. In athletes of the mesomorphic somatotype, the mode only had feedback with a thickness of 1 skin-fat fold (on the side) [18].

The amplitude of the wrestlers' mode had only $1(2.0 \%)$ reliable average feedback. The average $R-R$ interval, which reflects the balance of parasympathetic and sympathetic influences [24], had reliable feedbacks with $42.8 \%$ of the external body structure, including 21 medium strengths and 2 strong ones. It should be noted that this indicator of variational heart rate has significant correlations with almost the same constitutional parameters as mode, but the strength of the connections is somewhat smaller.

The maximum R-R interval for mesomorph wrestlers correlated statistically with $12(24.5 \%)$ anthropometric indicators, all correlations were inversely proportional to the mean force. We can predict that with decreasing total body size, pelvic diameters, muscle mass, this indicator will increase, and thus the variability of the heart rate of the parasympathetic department of the autonomic nervous system will be more pronounced $[3,25]$.

The minimal value of the R-R interval was varied with significant correlations with 17 parameters of the external structure of the body, among them the average mean force was $10(20.4 \%)$, the strong inverse - $1(2.0 \%)$, the direct average force $-5(10.2 \%)$, the strong direct $-1(2.0 \%)$. The peculiarities of established relationships between this indicator and constitutional characteristics confirm the established pattern that wrestlers of mesomorphic somatotype with increase of bone and muscle mass, individual body diameters and decrease of skin and fat folds will be observed decrease of the distance R-R and the greater will be the impact of the sympathetic department of the autonomic nervous system [13, 17]. The variational range had only significant mean power inverse correlations with $5(10.2 \%)$ indicators of the external structure of the body.

It should be noted that all statistical indicators of heart rate variability with constitutional parameters in young wrestlers of mesomorphic somatotype had only inverse significant correlations, mainly of average power. The SDNN was only associated with the value of only $3(6.1 \%)$ anthropometric indicators indicating subcutaneous fat deposition and muscle size. RMSSD had the most numerous and highest correlation strength among all statistical cardiointervalographic parameters, it was associated with $26(53.1 \%)$ somatic dimensions, of which 2 had strong relationships. The established nature of the relationships suggests that with decreasing anthroposomatotypological parameters in mesomorph wrestlers, the standard deviation of the difference of consecutive R-R intervals will increase and will be dominated by parasympathetic activity, which will reflect sinus arrhythmia associated with respiratory movements [21].

The PNN50 had a significant mean association with 14 $(28.6 \%)$ constitutional parameters, with the strongest correlation with muscle mass. It should be noted that all heart rate variability statistics had reliable feedback on muscle size.

Spectral indices of mesomorphic type wrestlers, which in athletes [18], were found to have the least significant correlation with external body size compared to other cardiointervalographic parameters.

The total recording power in all ranges had only 2 significant direct average correlation strength with the external body structure index (4.0\%). Power at very low frequencies, which reflects the activity of neurohumoral 
regulation of angiotensin, chemoreceptive and thermoregulatory systems [3, 13], was directly correlated with $12(24.5 \%)$ anthropometric parameters. The established nature of the relationship indicates that with the increase of total and longitudinal body sizes, the massiveness of the segments of the upper extremity and bone mass will increase the magnitude of this spectral index, and therefore will increase sympathetic influence through humoral regulation and increased activity [3]. The power in the low frequency range of mesomorph wrestlers correlated with 2 body sizes, but it is noteworthy that these connections were inverse. Power in the high-frequency range, which reflects the activity of the parasympathetic link [13], also had a small number of significant correlations $(4.0 \%)$, all correlations were direct.

We found that the indicators of vegetative homeostasis by the Baevsky method in wrestlers of adolescent mesomorphic somatotype with constitutional parameters had only direct reliable correlations. The voltage index of the regulatory systems was interrelated with $4(8.2 \%)$ constitutional parameters, the nature of the detected connections indicates that the activity of sympathetic regulation mechanisms will increase with the increase of longitudinal body size and muscle mass [3, 13]. The vegetative equilibrium index is also linked to 4 constitutional parameters, including the height of the upper thoracic point, intertrochanteric, muscular, and bone. Vegetative rhythm index had the highest number of significant correlations $(40.8 \%)$ in comparison with other spectral parameters. It has been found that with increasing total, longitudinal body sizes, chest and pelvis size, bone and muscle mass, this indicator will increase and thus the vegetative balance will be less shifted to the parasympathetic side [13].

The obtained results make it possible to apply the stepwise regression analysis method to develop normative

\section{References}

[1] Abbasova, E. A. (2016). Adaptation capabilities of athletes with various sports experience. National Institute of Sports Medicine and Rehabilitation, 3, 87-91.

[2] Akhmetov, S. M., Aleksanyants, G. D., \& Chernyshenko, Yu. K. (2011). The main research areas of the team of the Kuban State University of Physical Culture, Sports and Tourism. Physical culture, sport - science and practice, 2, 3-7.

[3] Bricout, V., Dechenaud, S., \& Favre-Juvin, A. (2010). Analyses of heart rate variability in young soccer players: The effects of sport activity. Autonomic neuroscience: basic \& clinical, 154(1-2), 112-116. doi: 10.1016/j.autneu.2009.12.001

[4] Bunak, V. V. (1941). Anthropometry: a practicalcourse. M.: Uchpedgiz.

[5] Carter, J. L., \& Heath, B. H. (1990). Somatotyping - development and applications. Cambridge University Press.

[6] Flatt, A. A., Esco, M. R., Allen, J. R., \& Robinson, J. B. (2018). Heart Rate Variability and Training Load Among National Collegiate Athletic Association Division 1 College Football Players Throughout Spring Camp. J. Strength. Cond. Res., 32(11), 3127-3134. doi: 10.1519/JSC.0000000000002241

[7] Ishchenko, G. O. (2014). Features of correlation of cardiointervalography indices and anthropo-somatotypological individual cardiointervalographic indicators in the wrestlers of the mesomorphic somatotype depending on the features of the body structure.

\section{Conclusions}

1. It was found that in youth wrestlers belonging to the mesomorphic somatotype, the indicators of variational heart rate had the highest number and strength $(r=0.42-$ 0.74 ) of statistically significant correlations with external body size and components of somatotype and body weight. The most reliable relationships were found for mode (63.3\% of all possible), average R-R interval (42.8\%), and minimum R-R interval (34.7\%). Most anthropometric parameters have inverse correlations of average strength, except for the thickness of the skin-fat folds where the correlations are straight.

2. It was found that among statistical indicators of heart rate variability, RMSSD with constitutional parameters had the highest number $(53.1 \%)$ and strength $(r=-0.41--0.69)$ of significant correlations. All the trusted correlations found were feedback. All statistics data had significant correlations with muscle size.

3. The least significant correlations with the constitutional characteristics of mesomorph wrestlers had spectral indices, except for the power at very low frequencies $(24.5 \%)$ and vegetative homeostasis indices by Baevsky, except for the vegetative rhythm index $(40.8 \%)$.

4. The revealed nature of the relationship in the wrestlers of the mesomorphic somatotype between all cardiointervalographic parameters and indicators of the external structure of the body indicates that with the increase of total, longitudinal, circumferential, transverse body sizes and muscle and bone mass, the activity of sympathetic regulation mechanisms will increase.

parameters of practically healthy men and women of Podillya of the first mature age. Ukrainian Medical Almanac, 6(6), 2023.

[8] Kellmann, M., Bertollo, M., Bosquet, L., \& Brink, M. (2018). Recovery and Performance in Sport: Consensus Statement. International journal of sports physiology and performance, 13(2), 240-245. doi: 10.1123/ijspp.2017-0759

[9] Kim, S., Zemon, V., Lehrer, P., McCraty, R., Cavallo, M. M., Raghavan, P. ... Foley, F. W. (2019). Emotion regulation after acquired brain injury: a study of heart rate variability, attentional control, and psychophysiology. Brain Inj., 33(8),1012-1020. doi: 10.1080/02699052.2019.1593506

[10] Koveshnikov, V. G., \& Nikityuk, B. A. (1992). Medical anthropology. Kiev: Health.

[11] Lehrer, P. M., \& Gevirtz, R. (2014). Heart rate variability biofeedback: how and why does it work? Front Psychol., 5, 756. doi: $10.3389 /$ fpsyg.2014.00756

[12] Malik, M., Bigger, J. T., Camm, A. J., Kleiger, R. E., Malliani, A., Moss, A. J., \& Schwartz, P. J. (1996). Heart rate variability. Standards of measurement, physiological interpretation, and clinical use. Task Force of the European Society of Cardiology and the North American Society of Pacing and 
Electrophysiology. European Heart Journal, 17, 354-381.

[13] Mazon, J. H., Gastaldi, A. C., Martins-Pinge, M. C., Eduardo de Araujo, J., \& Dutra de Souza, H. C. (2015). Study of Heart Rate Variability and Stress Markers in Basketball Players Submitted to Selective Loads Periodization System. American Journal of Sports Science, 3(3), 46-51. doi: 10.11648/ j.ajss.20150303.12

[14] Morales, A. P., Sampaio-Jorge, F., Rangel, L. F. C., Coe1ho, G. M. O., Leite, T. C., \& Ribeiro, B. G. (2014). Heart Rate Variability Responses in Vertical Jump Performance of Basketball Players. International Journal of Agriculture and Forestry, 4(2), 72-78. doi: 10.5923/j.sports.20140402.06

[15] Moroz, V. M., Sarafinyuk, L. A., \& Khapitska, O. P. (2016). Correlation of hemodynamic parameters hip with constitutional characteristics of sportsmen with mesomorphic somatotype. Biomedical and biosocial anthropology, 27, 112-118.

[16] Paul, M., \& Garg, K. (2012). The effect of heart rate variability biofeedback on performance psychology of basketball players. Appl. Psychophysiol. Biofeedback, 37(2), 131-44. doi: 10.1007/s10484-012-9185-2

[17] Rollo, S., Tracey, J., \& Prapavessis, H. (2017). Effects of a Heart Rate Variability Biofeedback Intervention on Athletes Psychological Responses Following Injury: APilot Study. Int J Sports Exerc Med, 3(081), 1-14. doi: 10.23937/2469-5718/ 1510081

[18] Sarafyniuk, L. A., Syvak, A. V., Yakusheva, Yu. I., \& Borejko, T. I. (2019) Correlations of cardiointervalographic indicators with constitutional characteristics in athletes of mesomorphic somatotype. Biomedical and biosocial anthropology, 35, 17-

\section{2. doi: 10.31393/bba34-2019-03}

[19] Sergeta, I. V., Gunas, I. V., Kovalchuk, V. V., \& Shipitsina, O. V. (2017). Features of correlation of heart rate variability with anthropo-somatotypologic body parameters of healthy healthy girls with different types of hemodynamics. J. of Morphology, 23(2), 327-331.

[20] Sessa, F., Anna, V., Messina, G., Cibelli, G., Monda, V., Marsala, G., ... \& Pisanelli, D. (2018). Heart rate variability as predictive factor for sudden cardiac death. Aging (Albany NY), 10(2), 166-177. doi: 10.18632/aging. 101386

[21] Shlak, N. E. (2015). Express estimation of functional readiness of an organism of the athlete for training and competitive actions (according to the analysis of heart rate variability). Science and sports: current trends, 4(9), 5-15.

[22] Skyba, O. (2017). Pathogenic specifics of development of vegetative dysfunction in adolescents in relation to their morphological status. Regulatory mechanisms in biosystems, 8(1),46-50. doi: 10.15421/021709

[23] Skyba, O., Pshenychna, L., \& Ustymenko-Kosorich, O. (2017). The features of vegetative regulation of the heart rate in athletes with different levels of perception and processing of visual information. Regulatory Mechanisms in Biosystems, 8(2), 239243. doi: $10.15421 / 021737$

[24] Vikulov, A. D., Bocharov, M. V., Kaunina, D. V., \& Boykov, V. L. (2017). Regulation of cardiac activity in highly qualified athletes. Biomedical problems of sports, 2, 31-36.

[25] Yakovleva, L. V., \& Guzel, N. S. (2015). Heart rate variability and psychological status in young hockey players. Kazan Medical Journal, 96(4), 675-679.

\section{ОСОБЛИВОСТІ ВЗАЄМОЗВ'ЯЗКІВ МІЖ КАРДІОІНТЕРВАЛОГРАФІЧНИМИ ПОКАЗНИКАМИ ТА КОНСТИТУЦІОНАЛЬНИМИ} ХАРАКТЕРИСТИКАМИ У ВИСОКОКВАЛІФІКОВАНИХ БОРЦІВ МЕЗОМОРФНОГО СОМАТОТИПУ

\section{Сивак А.В., Сарафинюк Л.А., Сарафинюк П.В., Пільганчук Л.І., Сорокіна Н.О.}

Механізми регуляції серцевого ритму мають безліч індивідуальних особливостей, котрі обумовлені віком, статтю, тренованістю організму, силою і характером зовнішнього впливу, конституціональними особливостями організму. Мета роботи - визначити взаємозв'язки між кардіоінтервалографрічними показниками та параметрами зовнішньої будови тіла у висококваліфікованих борців мезоморфнного соматотипу. У дослідженні взяли участь 24 борців у віці від 17 до 21 року з високим рівнем спортивної майстерності і стажем більше 3 років. Всі бориі були середніх вагових категорій $і$ займалися вільною та греко-римською боротьбою. Нами було проведене дослідження варіабельності серцевого ритму на кардіологічному комп'ютерному діагностичному комплексі "ОРТW" за рекомендаціями Європейської та Північноамериканської кардіологічної асоціації (1996]. Визначали показники вегетативного гомеостазу за Баєвським, варіаційної пульсометрії, статистичні та спектральні кардіоінтервалографрічні показники. Антропометрію проводили за методом В.В. Бунака (1941), соматотипологічне дослідження - за розрахунковою модифрікацією метода Heath-Carter (1990), визначення компонентного складу маси тіла за методом Матейко (1992). У пакеті "STATISTICA 5.5" був проведений кореляційний аналіз із використанням непараметричного статистичного методу Спірмена. Виявлено, що у борців мезоморфного соматотипу показники варіаційної пульсометрії мали з конституціональними параметрами найбільшу кількість та силу достовірних зв'язків, більшість з яких були зворотні середньої сили. Всі статистичні показники варіабельності серцевого ритму з показниками зовнішньої будови тіла мали лише зворотні достовірні кореляції. Найменшу кількість достовірних кореляцій виявлено для спектральних показників і параметрів вегетативного гомеостазу. За результатами кореляційного аналізу у борців мезоморфного соматотипу ми можемо припустити, що із збільшенням тотальних, поздовжніх, обхватних, поперечних розмірів тіла та м'язової та кісткової маси буде більш вираженим вплив на варіабельність серцевого ритму симпатичного відділу автономної нервової системи. Ключові слова: кореляції, кардіоінтервалографрічні показники, антропометричні розміри, соматотип, борці.

\section{ОСОБЕННОСТИ ВЗАИМОСВЯЗЕЙ МЕЖДУ КАРДИОИНТЕРВАЛОГРАФИЧЕСКИМИ ПОКАЗАТЕЛЯМИ И КОНСТИТУЦИОНАЛЬНЫМИ ХАРАКТЕРИСТИКАМИ У ВЫСОКОКВАЛИФИЦИРОВАННЫХ БОРЦОВ МЕЗОМОРФНОГО СОМАТОТИПА}

Сивак А.В., Сарафинюк Л.А., Сарафинюк П.В., Пильганчук Л.И., Сорокина Н.А.

Механизмы регуляции сердечного ритма имеют огромное количество индивидуальных особенностей, которые обусловлены возрастом, полом, тренированностью организма, силой и характером внешнего влияния, конституциональными особенностями организма. Цель работы - определить взаимосвязи между кардиоинтервалографрическими показателями и параметрами телосложения у высококвалифицированных борцов мезоморфного соматотипа. В исследовании участвовали 24 борца в возрасте от 17 до 21 года высокого уровня спортивного мастерства и со стажем более 3 лет. Все борцы были средних весовых категорий и занимались вольной и греко-римской борьбой. Нами было проведенное исследование вариабельности сердечного ритма на кардиологическом компьютерном диагностическом комплексе "ОРТW" по рекомендациям Европейской и 
Североамериканской кардиологической ассоциации (1996). Определяли показатели вегетативного гомеостаза по Баевскому, вариационной пульсометрии, статистические и спектральные кардиоинтервалографические показатели. Антропометрию проводили по методу В.В. Бунака (1941), соматотипологическое исследования - по расчетной модифрикации метода НеаthCarter (1990), определение компонентного состава массы тела по методу Матейко (1992). В пакете "STATISTICA 5.5" был проведен корреляционный анализ с использованием непараметрического статистического метода Спирмена. Выявлено, что у борцов мезоморфного соматотипа показатели вариационной пульсометрии имели с конституциональными параметрами наибольшее количество и силу достоверных связей, большинство из которых были обратные средней силы. Все статистические показатели вариабельности сердечного ритма с показателями телосложения имели лишь обратные достоверные корреляции. Наименьшее количество достоверных корреляций выявлено для спектральных показателей и параметров вегетативного гомеостаза. По результатам корреляционного анализа у борцов мезоморфрного соматотипа мы можем допустить, что $c$ увеличением тотальных, продольных, охватных, поперечных размеров тела, мышечной и костной массы будет более выраженное влияние на вариабельность сердечного ритма симпатичного отдела автономной нервной системы.

Ключевые слова: корреляции, кардиоинтервалографические показатели, антропометрические размеры, соматотип, борцы. 